\title{
A closer look at the role of urotensin II in the metabolic syndrome
}

\author{
Pierre-Olivier Barrette and Adel Giaid Schwertani* \\ Division of Cardiology, Department of Medicine, McGill University Health Center, Montreal, QC, Canada
}

\section{Edited by:}

Hubert Vaudry, University of Rouen,

France

\section{Reviewed by:}

Lan Ma, Fudan University, China Leo T. Lee, The University of Hong Kong, Hong Kong

\section{${ }^{*}$ Correspondence:}

Adel Giaid Schwertani, Division of Cardiology, Department of Medicine, McGill University Health Center, 1650 Cedar Avenue, Room C9-166, Montreal, OC, Canada H3G 1 A4. e-mail: adel.giaid@mcgill.ca
Urotensin II (UII) is a vasoactive peptide that was first discovered in the teleost fish, and later in mammals and humans. UII binds to the G protein coupled receptor GPR14 (now known as UT). UII mediates important physiological and pathological actions by interacting with its receptor. The metabolic syndrome (MetS) is described as cluster of factors such as obesity, dyslipidemia, hypertension, and insulin resistance (IR), further leading to development of type 2 diabetes mellitus and cardiovascular diseases. UII levels are upregulated in patients with the MetS. Evidence directly implicating UII in every risk factor of the MetS has been accumulated. The mechanism that links the different aspects of the MetS relies primarily on IR and inflammation. By directly modulating both of these factors, UII is thought to play a central role in the pathogenesis of the MetS. Moreover, Ull also plays an important role in hypertension and hyperlipidemia thereby contributing to cardiovascular complications associated with the MetS.

Keywords: metabolic syndrome, insulin resistance, inflammation, obesity, dyslipidemia, hypertension, diabetes

\section{UROTENSIN II}

The peptide Urotensin II (UII) was first identified in the teleost fish Gillichthys mirabilis (Pearson et al., 1980). Homologs of this peptide were subsequently found in mammals and humans (Pearson et al., 1980; Conlon et al., 1996; Ames et al., 1999; Coulouarn et al., 1999). Although the amino acid sequence of these homologs changes depending on the species, a cyclic sequence of six amino acids is conserved (Cys-Phe-Trp-Lys-Tyr-Cys). It is believed that this sequence is responsible for the biological activity of the peptide (Conlon et al., 1990). UII acts as a vasoactive peptide by binding to the $\mathrm{G}$ protein coupled receptor GPR14, better known as UT (Ames et al., 1999; Liu et al., 1999). A recent study has shown that UII vasoconstrictive effects are mediated by calcium influx via STIM1 and Orai-1 (Domínguez-Rodríguez et al., 2012). Human UII (hUII) and its receptor have been found in cardiac and vascular tissues, spinal cord, central nervous system, kidney, liver, and pancreas (Maguire et al., 2000; Matsushita et al., 2001). UII is also present in the blood plasma in picomolar concentrations (Matsushita et al., 2001). However, it tends to act mainly in an autocrine and paracrine fashion rather than as a hormone (Yoshimoto et al., 2004). Even though the relation between UII and its receptor was made in 1999, the physiological and pathological roles of UII are only beginning to be unraveled. In a healthy state, the binding of UII with UT is known to play an important role in the control of vascular tone, blood pressure, and insulin release (Douglas and Ohlstein, 2000; Douglas et al., 2000; Loirand et al., 2008). UII has been identified as the most potent vasoactive peptide known to date, being more potent vasoconstrictor than endothelin-1 and angiotensinII (Ames et al., 1999; Douglas and Ohlstein, 2000; Maguire et al., 2000). UII also controls the function of vascular smooth-muscle cells (VSMCs) through the release of endothelial-cell-derived vasodilators such as nitric oxide (Gibson, 1987; Gardiner et al.,
2001; Stirrat et al., 2001). The role of UII in pathological states is still debated. Many studies have shown increased levels of UII and its receptor in diverse cardiovascular and metabolic diseases such as type 2 diabetes mellitus, renal dysfunction, atherosclerosis, systematic and essential hypertension, obesity, congestive heart failure, myocardial infarction, cardiac fibrosis, hypertrophy, and remodeling (Reviewed in Hassan et al., 2003; Ross et al., 2010; Gruson etal., 2012). The elevated levels of UII in disease states suggest that UII is expressed either as a protective response to pathologies or as a pathological agent. Some studies claim that temporary elevation of UII levels may lower cardiovascular disease risk factors in end-stage renal disease (Mallamaci etal., 2005; Zoccali etal., 2006), myocardial infarction (Babińska etal., 2012) and restore endothelial function (Zoccali and Mallamaci, 2008). On the other hand, other studies have demonstrated that UII acts as a pathological agent inducing cardiac hypertrophy in synergy with angiotensin II by phosphorylation of the Akt kinase (Chanalaris et al., 2005; Gruson et al., 2010b, 2012).

\section{METABOLIC SYNDROME}

As mentioned above, the metabolic syndrome (MetS) consists of a set of risk factors, such as obesity, hyperlipidemia, hypertension, hyperglycemia, and insulin resistance (IR), leading to the development of type 2 diabetes, cardiovascular diseases, non-alcoholic fatty liver disease, and renal impairment (Grundy, 1999; Cho, 2011). The relation between these risk factors and complications seems to be mostly attributed to IR (Eckel et al., 2010), which is why the syndrome was first defined as an IR syndrome (Reaven, 1988). Since then, the National Cholesterol Education Program (NCEP)-Adult Treatment Panel III, the World Health Organization (WHO) and the International Diabetes Federation (IDF) set up some criteria for the clinical definition of MetS. 
A recent study using data from the 2003-2006 National Health and Nutrition Examination Survey and the NCEP/IDF MetS criteria, revealed that the prevalence of MetS was 34.3\% among all adults in the US (Ford et al., 2010). However, high prevalence of MetS is not only restricted to the Western world. MetS seems to be highly prevalent in sub-Saharan Africa, Middle-East, South America, and South Asian Countries (Misra and Khurana, 2008). Central obesity is considered the main precursor to MetS (Cameron et al., 2008). According to the WHO, the global obese population increased from 200 million in 1995 to 300 million in 2000. The WHO has also determined that the obesity epidemic is also spreading in developing countries with over 115 million people suffering from obesity-related illnesses (Misra and Khurana, 2008; WHO, 2008). Popkin and Doak (1998) have also reported increasing obesity prevalence in the United States, Latin America, Europe, and Asia, which confirms the worldwide epidemic proportions of obesity and overweight. In addition, the Aerobic Center Longitudinal Study, which included 33,230 cancer-free men followed for 14 years, showed $56 \%$ enhanced risk of cancer mortality for men affected by MetS (Jaggers et al., 2009). The direct implication of the syndrome in CVD, type 2 diabetes, non-alcoholic fatty liver, and cancer, as well as an increasing prevalence of obesity and decreased physical inactivity in Western societies makes the MetS a major health preoccupation (NCEP, 2002)

Recent researches have shown that UII has an impact on the risk factors as well as the overall pathogenesis of the MetS (Ong et al., 2008). A study using the American Heart Association/National Heart, Lung, and Blood Institute criteria for MetS revealed that MetS patients show higher plasma levels of UII (Gruson et al., 2010a). Our group also demonstrated an increase in UII plasma levels in mice when all risk factors of MetS are present (You et al., 2012). Moreover, we recently found that UII gene deletion in mice (UIIKO) significantly decreased body mass, visceral fat, blood pressure, and increased insulin and glucose tolerance when compared to wild-type mice (You et al., 2012). Even though there is a clear association between MetS and UII, it is still unclear whether the peptide plays a role in the initiation of the disease, or if the elevated plasma levels of UII are a result of the syndrome. This review aims to give a closer look at the implication of UII in the risk factors and pathways involved in the development of the MetS.

\section{INSULIN RESISTANCE (IR)}

Insulin plays a major role in glucose and lipid metabolism such as adipose tissue triglyceride lipolysis, lipoprotein lipase activity, muscle and adipose tissue glucose absorption, muscle and liver glycogen synthesis, and endogenous glucose production (Cornier et al., 2008). When cells react poorly to an insulin stimulus, they are defined as IR. The latter is known to be the link between the individual components of MetS (Eckel et al., 2010). For instance, it seems that IR correlates positively with atherosclerosis (Fernández-Real and Ricart, 2003) and coronary artery disease (CAD; Juhan-Vague et al., 1991), and also an indirect cause of hyperinsulinemia (Reaven, 2003), dyslipidemia, hyperglycemia, and hypertension (Sowers, 2004) through an increase in free fatty acid (FFA) synthesis in adipose tissue (Boden and Shulman, 2002) and a chronic inflammatory response (Fernández-Real and Ricart, 2003).
The IR Atherosclerosis Study (IRAS) and the Atherosclerosis Risk in Communities Study showed that insulin sensitivity (measured with an intravenous glucose tolerance test) correlates negatively with intimal-medial thickness of the carotid artery (Howard et al., 1996). Subsequent studies also found a significant correlation between carotid intimal-media thickening and IR and hyperinsulinemia (Golden et al., 2002; Zavaroni et al., 2006). Intimal-media thickness has been shown to be a significant predictor of myocardial infarction and coronary death (Hodis et al., 1998). As a result, IR is a major risk factor in developing cardiovascular complications. Indeed, IR has been associated with increased plasma levels of plasminogen activator inhibitor 1 (PAI-1; JuhanVague et al., 1991). Increased levels of PAI-1 are known to impair fibrinolysis, which leads to progression of coronary atherosclerosis in glucose intolerant patients (Bavenholm et al., 1998) and increased risk of myocardial reinfarction within 3 years in less than 45-year-old men (Hamsten et al., 1985, 1987; Gram et al., 1987; Juhan-Vague et al., 1991) as well as increased risk of CAD (JuhanVague et al., 1991). UII is known to increase expression of PAI-1 in vascular SMC (Djordjevic et al., 2005), hence UII may contribute to atherosclerosis through PAI-1 inhibition of fibrinolysis.

Free fatty acids play an important role in MetS by having direct effects on dyslipidemia, hypertension (Fagot-Campagna et al., 1998), IR (Boden, 1997), and pancreatic $\beta$-cell dysfunction (Sako and Grill, 1990; Unger, 1995; McGarry and Dobbins, 1999; Boden and Shulman, 2002). Impaired insulin action in adipose tissue tends to increase FFAs concentrations in the plasma by reducing the insulin inhibition of adipose tissue triglyceride lipolysis (Randle et al., 1963; Randle, 1998; Kahn and Flier, 2000; Cornier et al., 2008). On the other hand, FFAs induce IR in skeletal muscles (DeFronzo et al., 1985) and liver by inhibiting insulin suppression of glycogenolysis (Boden et al., 2002), which results in a vicious cycle increasing IR, FFA levels, and promotion of hyperglycemia. Furthermore, higher plasma glucose and FFA levels tend to increase insulin secretion in the pancreas (Boden and Shulman, 2002), thus leading to hyperinsulinemia. Such high plasma insulin levels promote hypertension (Welborn et al., 1966; Reaven, 2003), which is another risk factor of MetS. An increase in FFA levels also predicts development of type 2 diabetes (Paolisso et al., 1995; Charles et al., 1997). In the liver, higher FFA levels increase low density lipoprotein (LDL) and triglyceride production, while lowering high density lipoprotein (HDL) production (Brinton et al., 1991; Muramaki et al., 1995).

The direct effects of UII on lipid mobilization and FFA release are somewhat contradictory. In the coho salmon, administration of UII stimulated the activity of triacylglycerol lipase and the release of FFAs in the liver (Sheridan and Bern, 1986; Sheridan et al., 1987). On the contrary, UII injection in dogfish showed no significant increase in FFA release or plasma triglyceride concentrations (Conlon et al., 1994). We recently found that UII gene deletion in mice fed high fat diet significantly reduced serum levels of FFAs in comparison with wild-type (You et al., 2012). In light of our own findings and those of others linking UII to IR and glucose metabolism (Silvestre et al., 2001, 2004; Ong et al., 2006; You et al., 2012), we suggest that UII may mediate lipid mobilization and FFA indirectly through IR. However, the direct influence of UII in lipid metabolism still requires further research. 
The role of UII in the MetS seems to be closely related to insulin activity and the overall glucose metabolism in the pancreas (Figure 1). In fact, UII and UT are both expressed in rat pancreatic islets, where their interaction seems to inhibit glucosemediated insulin release (Silvestre et al., 2001, 2004). Also, when high concentrations of UII are administrated to the rat pancreas, glucose and arginine induced insulin response are blocked (Silvestre et al., 2001, 2004). Some UII and UT gene haplotypes are known to be associated with IR (Ong et al., 2006), impaired glucose tolerance (Ong et al., 2006), $\beta$-cell pancreatic function, and type 2 diabetes (Sun et al., 2002; Zhu et al., 2002; Wenyi et al., 2003; Suzuki et al., 2004; Tan et al., 2006; Sáez et al., 2011). UII upregulation in plasma and skeletal muscle in type 2 diabetes mellitus is coherent with this association (Totsune et al., 2003; Wang et al., 2009). In addition, UII increases glucose-6-phosphatase activity in salmon liver, which tends to reduce glycogen content and increase glucose levels, leading to hyperglycemia. Our recent study has demonstrated that UII gene knockout in mice reduced serum glucose and insulin, and increased glucose and insulin tolerance in comparison with wild-type mice (You et al., 2012).

\section{INFLAMMATORY RESPONSE IN THE MetS}

It is well known that IR and MetS are both associated with an inflammatory response (Sutherland etal., 2004). The relationship between IR and inflammation seems to be bidirectional; IR promotes an inflammatory response and vice versa (FernándezReal and Ricart, 2003), resulting in a vicious circle increasing risk of MetS incidence. An acute-phase inflammatory response is not only linked with IR (Fernández-Real et al., 2001; Festa et al., 2002; Grimble, 2002; Leinonen et al., 2003), but also with type 2 diabetes (McMillan, 1989; Arnalich et al., 2000; Festa et al., 2002; Leinonen et al., 2003), obesity (Laimer et al., 2002; Leinonen et al., 2003), and the overall MetS (Chan et al., 2002; Das, 2002). The activity of inflammatory markers such as C-reactive protein, tumor necrosis factor-alpha (TNF- $\alpha$ ), Interleukin-18 (IL-18) and PAI-1 increases as the presence of MetS risk factors increase (Cornier et al., 2008).

Tumor necrosis factor-alpha prevents the action of insulin in cultured cells and in animal models (Hotamisligil et al., 1993, 1994, 1996) by inducing serine phosphorylation of the insulin receptor substrate-1, which reduces the tyrosine kinase activity

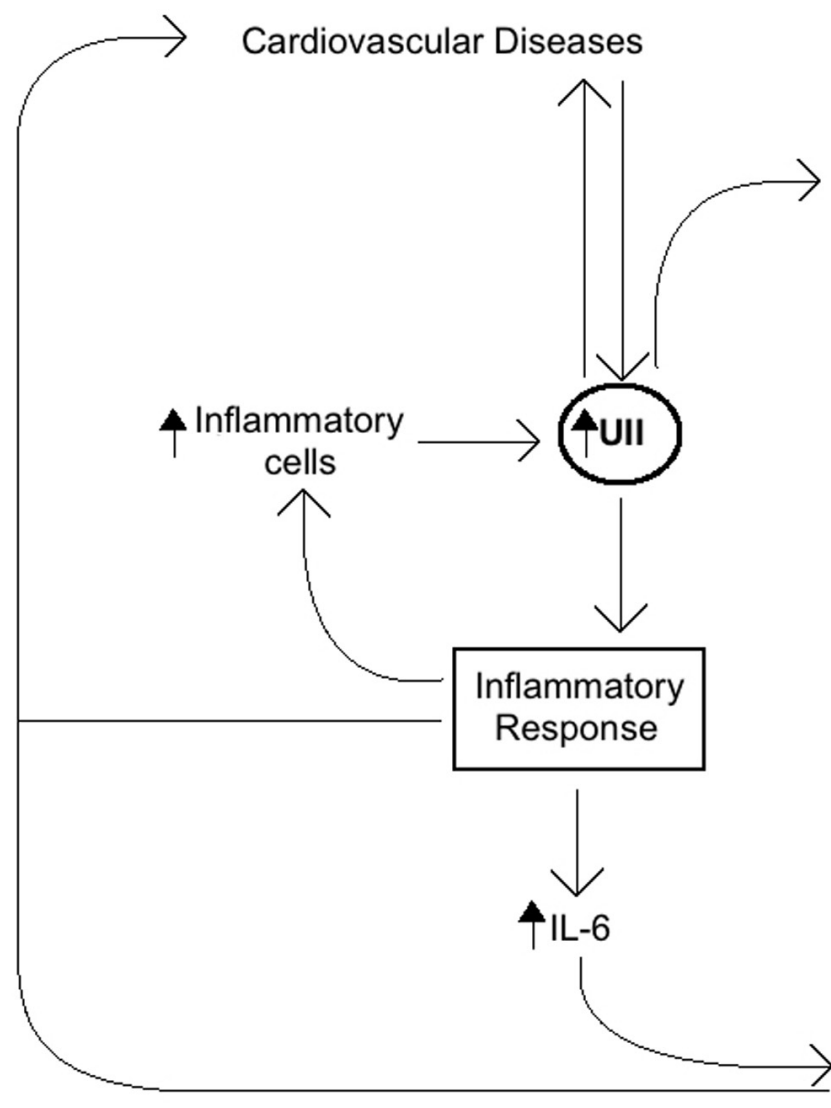

FIGURE 1 | Summary of the role of Urotensin II (UII) on insulin activity and glucose metabolism associated with the metabolic syndrome. UII expressed in the pancreas acts directly to impair glucose tolerance, reduce

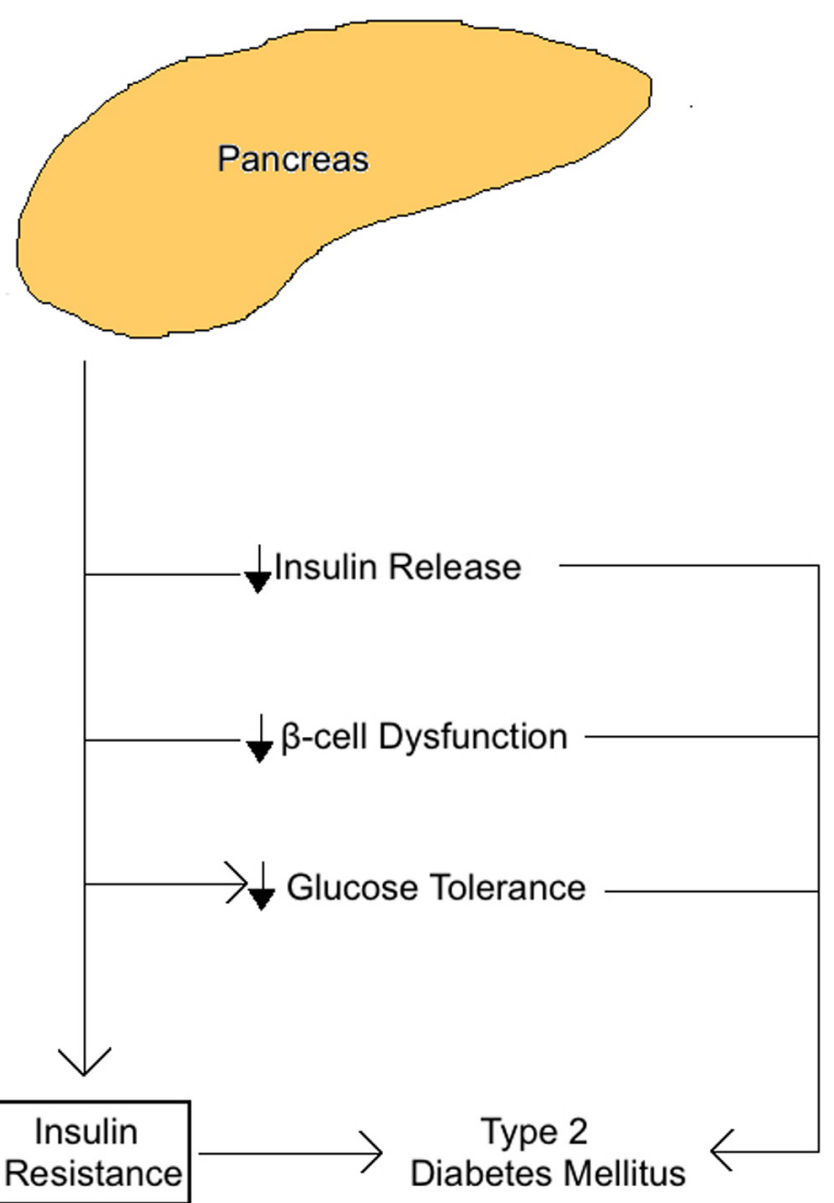

glucose-mediated insulin release, impair pancreatic $\beta$-cell function, and block insulin response resulting in IR and increased risk of type 2 diabetes and cardiovascular diseases. 
of the insulin receptor (Hotamisligil et al., 1996), resulting in IR. Furthermore, TNF- $\alpha$ stimulates the production of endothelin-1 (Kahaleh and Fan, 1997) and angiotensin (Brasier et al., 1996) in vitro, which are directly involved in vasoconstriction and thus may lead to increased hypertension. Indeed, there is a positive correlation between TNF- $\alpha$, systolic blood pressure, and IR (Dörffel et al., 1999). TNF- $\alpha$ also stimulates VLDL production (Grunfeld and Feingold, 1992) and decreases HDL cholesterol (Jovinge et al., 1998). Dyslipidemia in mice is significantly related to increased TNF- $\alpha$ levels (Fleet et al., 1992).

Elevated levels of the inflammatory cytokine IL-6 are associated with obesity, IR (Fried et al., 1998; Bastard et al., 2000; Fernández-Real et al., 2001; Kern et al., 2001; Bastard et al., 2002), and type 2 diabetes (Pradhan et al., 2001; Vozarova et al., 2003). IL-6 also plays a role in the pathology of dyslipidemia by decreasing LPL activity in adipocytes (Greenberg et al., 1992) which increases hepatic triglyceride levels (Nonogaki et al., 1995). In man, IL-6 correlates with increased FFA (Stouthard et al., 1995), fasting triglycerides, and VLDL (Fernández-Real et al., 2000), and decreased HDL cholesterol (Zuliani et al., 2007). This cytokine may also have an impact on hypertension by stimulating the sympathetic and central nervous system (Besedovsky and Del Rey, 1996; Papanicolaou et al., 1996), and angiotensin expression (Takano et al., 2000).

The central role of the inflammatory response in MetS is also related to UII and UT expression (Figure 2). Inflammatory cells including lymphocytes, macrophages, monocytes, and foam cells express UII and UT mRNA (Bousette et al., 2004). Lymphocytes are by far the largest producers of UII, whereas monocytes and macrophages produce the highest levels of UT. Moreover, inflammatory markers such as TNF- $\alpha$, lipopolysaccharide, and interferon- $\gamma$ are all known to induce UT expression in vitro (Segain et al., 2007). These findings suggest that an inflammatory response to MetS and its components may increase UII levels by increasing inflammatory cells production of the peptide. On the other hand, UII is known to contribute to the inflammatory response by inducing the release of inflammatory cytokines like IL-6 in cardiomyocytes (Sano et al., 2000; Tzanidis et al., 2003; Johns et al., 2004; Russell and Molenaar, 2004). UII mediates aortic inflammation by stimulating the release of leukotriene $\mathrm{C}\left(\mathrm{LTC}_{4}\right)$, a lipid inflammatory mediator, from aortic adventitial fibroblasts through 5-lipoxygenase pathway (Dong

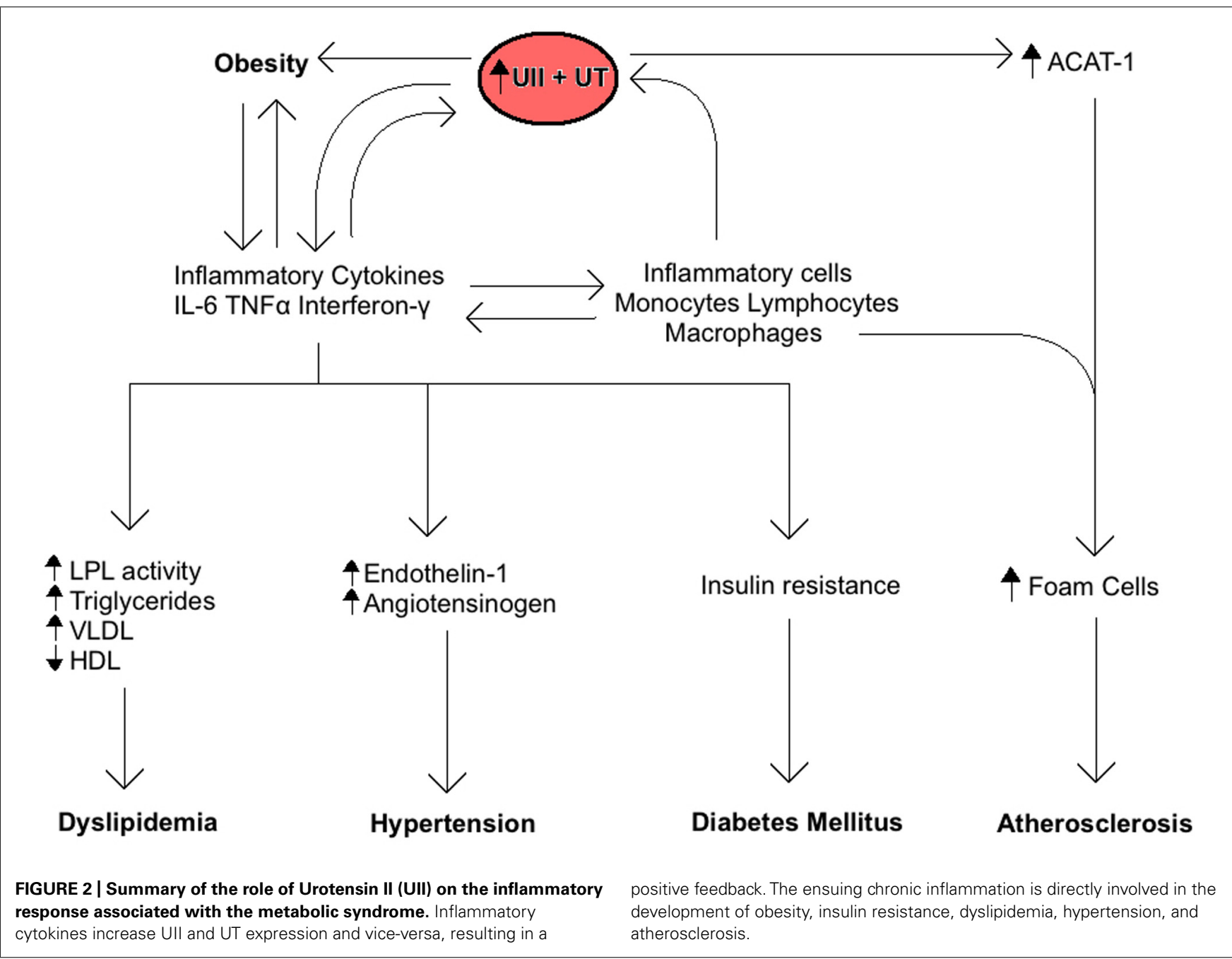


et al., 2012). LTC $_{4}$ plays a key role in the pathogenesis of atherosclerosis as a chemoattractant and activator for monocytes in the vascular endothelium. It is also known to initiate contraction of smooth muscle cells in the adjacent medial tissues of the vasculature (Dong et al., 2012). In addition, we have recently shown that UII gene deletion in mice fed a high fat diet reduces the serum levels of inflammatory cytokines including monocyte chemoattractant protein-1, monokine induced by $\gamma$-interferon, and keratinocyte chemoattractant when compared to wild-type mice (You et al., 2012).

\section{UII, HYPERTENSION, AND CARDIOVASCULAR DISEASES}

The MetS is identified as a clustering of risk factors that perpetuate cardiovascular diseases. Since UII has been shown to play a role in the pathogenesis of atherosclerosis (Maguire et al., 2004; Hassan et al., 2005; Papadopoulos et al., 2009), congestive heart failure (Hassan et al., 2003), myocardial ischemia (Zhang et al., 2002; Zhou et al., 2003), ventricular hypertrophy, and fibrosis (Sano et al., 2000; Tzanidis et al., 2003; Johns et al., 2004; Russell and Molenaar, 2004), it is therefore reasonable to suggest that induction of UII in the MetS may contribute to the cardiovascular abnormalities associated with this syndrome.

Atherosclerosis is the main cause of morbidity and mortality in cardiovascular diseases and cause of death in the Western world (Libby et al., 2009). Atherosclerosis is known to induce UT and UII overexpression in mice aortic tissues (Douglas et al., 2002; Bousette et al., 2004; Wang et al., 2006; Libby et al., 2009). In mice overexpressing $\mathrm{UT}$ receptor $\left(\mathrm{UT}^{+}\right)$, aortic atherosclerosis lesion formation is significantly increased (Papadopoulos et al., 2009), whereas lesion formation is decreased in UIIKO mice with an atherosclerotic background (APOE; You et al., 2012). UII is known to promote vascular remodeling by mediating VSMC proliferation and migration inside the intima, a process directly involved in atherogenesis (Sauzeau et al., 2001; Watanabe et al., 2001a,b; Tamura etal., 2003; Albertin etal., 2009; Iglewski and Grant, 2010). It has been suggested that vascular endothelial growth factor (VEGF), a major angiogenic protein, could be responsible for UII-mediated vascular remodeling. Even though UII does not affect VEGF expression in human endothelium (Albertin et al., 2009), recent evidence has shown that UII induces secretion of VEGF in the adventitia in synergy with angiotensin II (Song et al., 2012). VEGF stimulates proliferation of endothelial and smooth muscles cells while also stimulating proliferation and migration of adventitial fibroblasts in the intima (Sartore et al., 2001; Stenmark et al., 2006; Zhang et al., 2008). In addition, UII contributes to the inflammatory response in atherosclerosis by acting as a chemoattractant for monocytes (Segain et al., 2007) and increasing IL-6 expression in cardiomyocytes (Sano et al., 2000; Tzanidis et al., 2003; Johns et al., 2004; Russell and Molenaar, 2004). UII interacts with UT receptors on the surface of macrophages to promote expression of ACAT-1 (Watanabe et al., 2005). ACAT-1 is known to accelerate foam cells formation, which has a major impact on atherosclerotic lesion development (Watanabe et al., 2005). Another main effect of UII on atherosclerosis is the increased expression of NADPH oxidase, which is a main source of reactive oxygen species (ROS; Djordjevic et al., 2005; Tsoukas et al., 2011). ROS are central in the early initiation of atherosclerosis by converting LDL into oxidized-LDL (Djordjevic etal., 2005). NADPH oxidase-derived superoxide inactivates nitric oxide, resulting in impaired endothelial dependant vasodilatation (Zou et al., 2004) and hypertension (Lassègue and Clempus, 2003).

Urotensin II also contributes to essential (Matsushita et al., 2001) and secondary (Heller et al., 2002) hypertension by inducing vascular remodeling. Increased blood pressure in cats (Behm et al., 2004), rats (Lin et al., 2003), and sheep (Watson et al., 2003) with UII administration is coherent with these findings. In humans, plasma UII correlates positively with systolic blood pressure, independently of an atherosclerotic background (Cheung et al., 2004). Indeed, the UII gene (UTS2) is associated with essential hypertension (Yi et al., 2006) and myocardial infarction (Nishihama et al., 2007; Oguri et al., 2009). In a chronic heart failure or essential hypertension state, UII loses its dilatory function (Lim et al., 2004; Sondermeijer et al., 2005).

\section{UII, OBESITY, AND HYPERLIPIDEMIA}

Obesity seems to be a main cause of IR in both men and women (Carey etal., 1996; Cornier etal., 2008; Stefan et al., 2008). Moreover, it seems that physical activity and a diet rich in monounsaturated or hydrogenated fat leads to an impairment of insulin sensitivity (Mayer-Davis et al., 1998; Vessby et al., 2001; Han et al., 2002). Obesity is also known as a chronic inflammatory state; it induces release of proinflammatory cytokines and adipokines (Yudkin et al., 1999; Festa et al., 2001; Engström et al., 2003; Trayhurn and Wood, 2004). As a result, the pathologic role of inflammation in IR and MetS may be enhanced by obesity. However, some suggest that obesity may be, on the opposite, an outcome of inflammation (Das, 2001). Obesity may contribute to increase local IR in the adipocytes as well as in other tissue such as the liver and skeletal muscles (Cornier et al., 2008; Gregor and Hotamisligil, 2011).

Plasma UII correlates positively with body weight in humans independently of atherosclerotic background (Cheung etal., 2004). Adipokines (dipeptidyl peptidase-4, endocan, insulin-like growth factor-binding proteins), known to play a role in diabetes mellitus and obesity (Janke et al., 2006; Neumiller et al., 2010; Ruan and Lai, 2010) were reduced in UII/ApoE double knockout mice in comparison with ApoEKO (You et al., 2012). Reduction of body mass, visceral fat, visceral adipocytes diameter, serum LDL, triglycerides, as well as increase in HDL is also observed with UII gene deletion in mice (You et al., 2012; Figure 3). A reduction in hepatic cholesterol esterification is also observed in UIIKO mice (Kiss et al., 2011). These results are attributed to a reduction in cholesterol and apolipoprotein B production by hepatocytes (Kiss et al., 2011). Furthermore, Jiang et al. (2008) found that the UII gene (UTS2) regulates fat accumulation in humans.

\section{CONCLUSION}

The mechanism that links the various components of MetS relies primarily on IR and inflammation (Sutherland et al., 2004; Eckel et al., 2010). The ability of UII to modulate both of these factors suggests an important role for the peptide in the pathogenesis of the MetS. Other risk factors mediated by UII, such as obesity, may tend to initiate the positive feedback cycle, which contributes to 
A

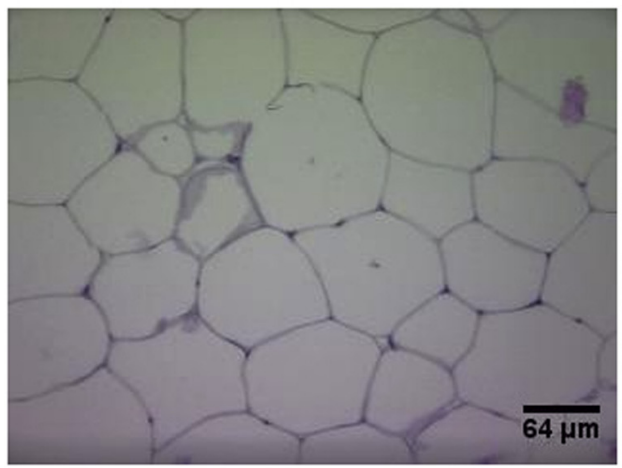

B

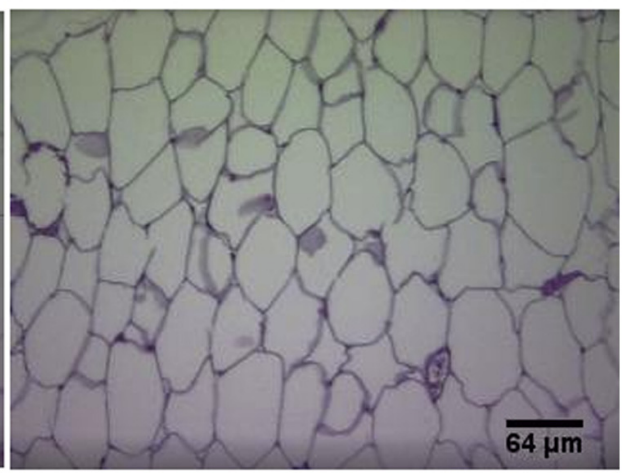

FIGURE 3 | Hematoxylin and eosin staining of visceral adipose tissue sections in wild-type mice (A) and UIIKO mice (B). Adipocytes of UIIKO mice appear smaller than wild-type mice.

the development of MetS. In fact, genetic manipulation or the use of UT receptor antagonists seems to have a positive effect on every risk factor of the MetS (You et al., 2012). However, it is still unclear whether UII is important in the initiation or only in the progression and further complications of the disease. The biological activities of UII, and the recent reports of increased serum levels of UII in patients with the MetS suggest that pharmacological manipulation of the UII pathway as a possible future treatment of the syndrome.

\section{ACKNOWLEDGMENTS}

We acknowledge the support of the Canadian Institute of Health Research and the Heart and Stroke Foundation of Quebec. We also thank Zhipeng You for his technical help.

\section{REFERENCES}

Albertin, G., Guidolin, D., Sorato, E., Spinazzi, R., Mascarin, A., Oselladore, B., etal. (2009). Proangiogenic activity of UrotensinII on different human vascular endothelial cell populations. Regul. Pept. 157, 64-71.

Ames, R. S., Sarau, H. M., Chambers, J. K., Willette, R. N., Aiyar, N. V., Romanic, A. M., etal. (1999). Human urotensin-II is a potent vasoconstrictor and agonist for the orphan receptor GPR14. Nature 401, 282-286.

Arnalich, F., Hernanz, A., LopezMaderuelo, D., Peña, J. M., Camacho, J., Madero, R., etal. (2000). Enhanced acute-phase response and oxidative stress in older adults with type II diabetes. Horm. Metab. Res. 32, 407-412.

Babińska, M., Holecki, M., Prochaczak, F., Owczarek, A., Kokocińska, D., Chudek., J., et al. (2012). Is plasma urotensin II concentration an indicator of myocardial damage in patients with acute coronary syndrome? Arch. Med. Sci. 8, 449-454.

Bastard, J. P., Jardel, C., Bruckert, E., Blondy, P., Capeau, J., Laville, M., et al. (2000). Elevated levels of interleukin 6 are reduced in serum and subcutaneous adipose tissue of obese women after weight loss. J. Clin. Endocrinol. Metab. 85, 3338-3342.
Bastard, J. P., Maachi, M., Van Nhieu, J. T., Jardel, C., Bruckert, E., Grimaldi, A., et al. (2002). Adipose tissue IL-6 content correlates with resistance to insulin activation of glucose uptake both in vivo and in vitro. J. Clin. Endocrinol. Metab. 87, 2084-2089.

Bavenholm, P., de Faire, U., Landou, C., Efendic, S., Nilsson, J., Wilman, B., et al. (1998). Progression of coronary artery disease in young male post-infarction patients is linked to disturbances of carbohydrate and lipoprotein metabolism and to impaired fibrinolytic function. Eur. Heart J. 19, 402-410.

Behm, D. J., Doe, C. P., Johns, D. G., Maniscalco, K., Stankus, G. P., Wibberley, A., et al. (2004). Urotensin-II: a novel systemic hypertensive factor in the cat. Naunyn Schmiedebergs Arch. Pharmacol. 369, 274-280.

Besedovsky, H. O., and Del Rey, A. (1996). Immune-neuro-endocrine interactions. Endocr. Rev. 17, 64-102.

Boden, G. (1997). Role of fatty acids in the pathogenesis of insulin resistance and NIDDM. Diabetes 46, 3-10.

Boden, G., and Shulman, G. I. (2002). Free fatty acids in obesity and type 2 diabetes: defining their role in the development of insulin resistance and $\beta$-cell dysfunction. Eur. J. Clin. Invest. 32(Suppl. 3), 14-23.

Boden, G., Cheung, P., Stein, T. P., Kresge, K., and Mozzoli, M.
(2002). FFA cause hepatic insulin resistance by inhibiting insulin suppression of glycogenolysis. Am. J. Physiol. Endocrinol. Metab. 283, E12-E19.

Bousette, N., Patel, L., Douglas, S. A., Ohlstein, E. H., and Giaid, A. (2004) Increased expression of urotensin II and its cognate receptor GPR14 in atherosclerotic lesions of the human aorta. Atherosclerosis 176, 117-123.

Brasier, A. R., Li, J., and Wimbish, K. A. (1996). Tumor necrosis factor activates angiotensinogen gene expression by the Rel A transactivator. Hypertension 27, 1009-1017.

Brinton, E. A., Eisenberg, S., and Breslow, J. L. (1991). Increased apo Aand apo A-II fractional catabolic rate in patients with low high density lipoprotein-cholesterol levels with or without hypertriglyceridemia. J. Clin. Invest. 87, 536-544.

Cameron, A. J., Boyko, E. J., Sicree, R. A., Zimmet, P. Z., Söderberg, S., Alberti, K. G., et al. (2008). Central obesity as a precursor to the metabolic syndrome in the AusDiab study and Mauritius. Obesity (Silver Spring) 16, 2707-2716.

Carey, D. G., Jenkins, A. B., Campbell, L. V., Freund, J., and Chisholm, D. J. (1996). Abdominal fat and insulin resistance in normal and overweight women: direct measurements reveal a strong relationship in subjects at both low and high risk of NIDDM. Diabetes 45, 633-638.

Chan, J. C., Cheung, J. C., Stehouwer, C. D., Emeis, J. J., Tong, P. C., Ko, G. T., et al. (2002). The central roles of obesity-associated dyslipidaemia, endothelial activation and cytokines in the metabolic syndrome-an analysis by structural equation modelling. Int. J. Obes. Relat. Metab. Disord. 26, 994-1008.

Chanalaris, A., Lawrence, K. M., Townsend, P. A., Davidson, S., Jamshidi, Y., Stephanou, A., et al. (2005). Hypertrophic effects of urocortin homologous peptides are mediated via activation of the Akt pathway. Biochem. Biophys. Res. Commun. 328, 442-448.

Charles, M. A., Eschwege, E., Thicult, N., Claude, J. R., Warnet, J. M., Rosselin, G. E., et al. (1997). The role of non-esterified fatty acids in the deterioration of glucose tolerance in Caucasian subjects: results of the Paris Prospective Study. Diabetologia 40, 1101-1106.

Cheung, B. M., Leung, R., Man, Y. B., and Wong, L. Y. (2004). Plasma concentration of urotensin II is raised in hypertension. J. Hypertens. 22, 1341-1344.

Cho, L. W. (2011). Metabolic syndrome. Singapore Med. J. 52, 779-785.

Conlon, J. M., Agius, L., George, K., Alberti, M. M., and Hazon, N. (1994). 
Effects of dogfish urotensin II on lipid mobilization in the fasted dogfish, Scyliorhinus canicula. Gen. Comp. Endocrinol. 93, 177-180.

Conlon, J. M., Arnold-Reed, D., and Balment, R. J. (1990). Post-translational processing of prepro-urotensin II. FEBS Lett. 266, 37-40.

Conlon, J. M., Yano, K., Waugh, D., and Hazon, N. (1996). Distribution and molecular forms of urotensin II and its role in cardiovascular regulation in vertebrates. J. Exp. Zool. 275 , 226-238.

Cornier, M. A., Dabelea, D., Hernandez, T. L., Lindstrom, R. C., Steig, A. J., Stob, N. R., et al. (2008). The metabolic syndrome. Endocr. Rev. 29, $777-822$.

Coulouarn, Y., Jégou, S., Tostivint, H., Vaudry, H., and Lihrmann, I. (1999). Cloning, sequence analysis and tissue distribution of the mouse and rat urotensin II precursors. FEBS Lett. 457, 28-32.

Das, U. N. (2001). Is obesity an inflammatory condition? Nutrition 17, 953-966.

Das, U. N. (2002). Is metabolic syndrome $\mathrm{X}$ an inflammatory condition? Exp. Biol. Med. 227, 989-997.

DeFronzo, R. A., Gunnarsson, R., Björkman, O., Olsson, M., and Wahren, J. (1985). Effects of insulin on peripheral and splanchnic glucose metabolism in noninsulindependent (type II) diabetes mellitus. J. Clin. Invest. 76, 149-155.

Djordjevic, T., BelAiba, R. S., Bonello, S., Pfeilschifter, J., Hess, J., and Görlach, A. (2005). Human urotensin II is a novel activator of NADPH oxidase in human pulmonary artery smooth muscle cells. Arterioscler. Thromb. Vasc. Biol. 25, 519-525.

Domínguez-Rodríguez, A., Díaz, I., Rodríguez-Moyano, M., CaderónSánchez, E., Antonio, R. J., Ordóñez A., et al. (2012). Urotensin-II signalling mechanism in rat coronary artery: role of STIM1 and Oraildependant store operated calcium influx in vasoconstriction. Arterioscler. Thromb. Vasc. Biol. 35, 1325 1332.

Dong, X., Ye, X., Song, N., Zhao, J., Di, B., Peng, F., et al. (2012). Urotensin II promotes the production of LTC(4) in rat aortic adventitial fibroblasts through NF-kB-5-LO pathway by p38 MAPK and ERK activations. Heart Vessels doi: 10.1007/s00380 012-0291-0 [Epub ahead of print].

Dörffel, Y., Lätsch, C., Stuhlmüller, B., Schreiber, S., Scholze, S., Burmester, G. R., etal. (1999). Preactivated peripheral blood monocytes in patients with essential hypertension. Hypertension 34, 113-117.

Douglas, S. A., and Ohlstein, E. H. (2000). Human urotensin-II, the most potent mammalian vasoconstrictor identified to date, as a therapeutic target for the management of cardiovascular disease. Trends Cardiovasc. Med. 131, 1262-1274.

Douglas, S. A., Sulpizio, A. C., Piercy, V. Sarau, H. M., Ames, R. S., Aiyar, N. V., et al. (2000). Differential vasoconstrictor activity of human urotensinII in vascular tissue isolated from the rat, mouse, dog, pig, marmoset and cynomolgus monkey. Br. J. Pharmacol. 131, 1262-1274.

Douglas, S. A., Tayara, L., Ohlstein E. H., Halawa, N., and Giaid, A. (2002). Congestive heart failure and expression of myocardial urotensin II. Lancet 359, 1990-1997.

Eckel, R. H., Alberti, K. G., Grundy, S. M., and Zimmet, P. Z. (2010). The metabolic syndrome. Lancet 375 , 181-183.

Engström, G., Hedblad, B., Stavenow, L., Lind, P., Janzon, L., and Lindgärde, F. (2003). Inflammationsensitive plasma proteins are associated with future weight gain. Diabetes 52, 2097-2101.

Fagot-Campagna, A., Balkau, B., Simon, D., Warnet, J. M., Claude, J. R., Ducimetiere, P., et al. (1998). High free fatty acid concentration: an independent risk factor for hypertension in the Paris Prospective Study. Int. J. Epidemiol. 27, 808-813.

Fernández-Real, J. M., Broch, M., Vendrell, J., Richart, C., and Ricart, W. (2000). Interleukin 6 gene polymorphism and lipid abnormalities in healthy subjects. J. Clin. Endocrinol. Metab. 85, 1334-1339.

Fernández-Real, J. M., Vayreda, M., Richart, C., Gutiérrez, C., Broch, M. Vendrell, J., et al. (2001). Circulating interleukin 6 levels, blood pressure and insulin sensitivity in apparently healthy men and women. J. Clin. Endocrinol. Metab. 86, 1154-1159.

Fernández-Real, J. M., and Ricart, W. (2003). Insulin resistance and chronic cardiovascular inflammatory syndrome. Endocr. Rev. 24, 278-301.

Festa, A., D’Agostino, R. Jr., Williams, K., Karter, A. J., Mayer-Davis, E. J., Tracy, R. P., et al. (2001). The relation of body fat mass and distribution to markers of chronic inflammation. Int. J. Obesity 25, 1407-1415.

Festa, A., D'Agostino, R., Tracy, R. P., and Haffner, S. M. (2002). Elevated levels of acute-phase proteins and plasminogen activator inhibitor1 predict the development of type 2 diabetes. The insulin resistance atherosclerosis study. Diabetes 51 , 1131-1137.

Fleet, J. C., Clinton, S. K., Salomon, R. N., Loppnow, H., and Libby, P (1992). Atherogenic diets enhance endotoxin-stimulated interleukin-1 and tumor necrosis factor gene expression in rabbit aortae. J. Nutr. 122, 294-305.

Ford, E. S., Li, C., and Zhao, G. (2010). Prevalence and correlates of metabolic syndrome based on a harmonious definition among adults in the US. J. Diabetes 2, 180-193.

Fried, S. K., Bunkin, D. A., and Greenberg, A. S. (1998). Omental and subcutaneous adipose tissues of obese subjects release interleukin-6: depo difference and regulation by glucocorticoid. J. Clin. Endocrinol. Metab. $83,847-850$

Gardiner, S. M., March, J. E., Kemp P. A., Davenport, A. P., and Bennett, T. (2001). Depressor and regionally selective vasodilator effects of human urotensin II in conscious rats. $\mathrm{Br}$. J. Pharmacol. 132, 1625-1629.

Gibson, A. (1987). Complex effects of Gillichthys urotensin II on rat aortic strips. Br. J. Pharmacol. 91, 205-212.

Golden, S. H., Folsom, A. R., Coresh, J., Sharrett, A. R., Szklo, M., and Brancati, F. (2002). Risk factor groupings related to insulin resistance and their synergistic effects on subclinical atherosclerosis: the atherosclerosis risk in communities study. Diabetes 51, 3069-3076.

Gram, J., Jespersen, J., Kluft, C., and Rijken, D. C. (1987). On the usefulness of fibrinolysis variables in the characterization of a risk group for myocardial reinfarction. Acta. Med. Scand. 221, 149-153.

Greenberg, A. S., Nordan, R. P., McIntosh, J., Calvo, J. C., Scow, R. O. and Jablons, D. (1992). Interleukin6 reduces lipoprotein lipase activity in adipose tissue of mice in vivo and in 3T3-L1 adipocytes: a possible role for interleukin-6 in cancer cachexia. Cancer. Res. 52, 4113-4116.

Gregor, M. F., and Hotamisligil, G. S. (2011). Inflammatory mechanisms in obesity. Annu. Rev. Immunol. 23, 415-445.

Grimble, R. F. (2002). Inflammatory status and insulin resistance. Curr. Opin. Clin. Nutr. Metab. Care 5 , 551-559.

Grundy, S. M. (1999). Hypertriglyceridemia, insulin resistance, and the metabolic syndrome. Am. J. Cardiol. $83,25-29$.

Grunfeld, C., and Feingold, K. R. (1992). Role of cytokines in inducing hyperlipidemia. Diabetes 41(Suppl. 2), 97-101.
Gruson, D., Rousseau, M. F., Ketelslegers, J. M., and Hermans, M. P. (2010a). Raised plasma urotensin II in type 2 diabetes patients is associated with the metabolic syndrome phenotype. J. Clin. Hypertens. (Greenwich) 12, 653-660.

Gruson, D., Ginion, A., Decroly, N., Lause, P., Vanoverschelde, J. L., Ketelslegers, J. M., et al. (2010b). Urotensin II induction of adult cardiomyocytes hypertrophy involves the Akt/GSK-3beta signaling pathway. Peptides 31, 1326-1333.

Gruson, D., Ginion, A., Lause, P., Ketelslegers, J. M., Thissien, J. P., and Bertrand, L. (2012). Urotensin II and urocortin trigger the expression of myostatin, a negative regulator of cardiac growth, in cardiomyocytes. Peptides 33, 351-353.

Hamsten, A., Wiman, B., Defaire, U., and Blomback, M. (1985). Increased plasma level of a rapid inhibitor of tissue plasminogen activator in young survivors of myocardial infarction. $N$. Engl. J. Med. 313, 1557-1563.

Hamsten, A., Defaire, U., Walldius, G., Dahlen, G., Szamosi, A., Landov, C., et al. (1987). Plasminogen activator inhibitor in plasma: risk factor for recurrent myocardial infarction. Lancet 2, 3-9.

Han, S. N., Leka, L. S., Lichtenstein, A. H., Ausman, L. M., Schaefer, E. J., and Meydani, S. N. (2002). Effect of hydrogenated and saturated, relative to polyunsaturated, fat on immune and inflammatory responses of adults with moderate hypercholesterolemia. J. Lipid. Res. 43, 445-452.

Hassan, G. S., Chouiali, F., Saito, T., Hu, F., Douglas, S. A., Ao, Z., et al. (2003) Effect of human urotensin-II infusion on hemodynamics and cardiac function. Can. J. Physiol. Pharmacol. $81,125-128$.

Hassan, G. S., Douglas, S. A., Ohlstein, E. H., and Giaid, A. (2005). Expression of urotensin-II in human coronary atherosclerosis. Peptides 26 2462-2472.

Heller, J., Schepke, M., Neef, M., Woitas, R., Rabe, C., and Sauerbruch, T. (2002). Increased urotensin II plasma levels in patients with cirrhosis and portal hypertension. J. Hepatol. 37, 767-772.

Hodis, H. N., Mack, W. J., LaBree, L., Selzer, R. H., Liu, C. R., Liu, C. H., et al. (1998). The role of carotid arterial intima-media thickness in predicting clinical coronary events. Ann. Intern. Med. 128, 262-269.

Hotamisligil, G. S., Budavari, A., Murray, D., and Spiegelman, B. M. (1994). Reduced tyrosine kinase activity of the insulin receptor in 
obesity-diabetes. J. Clin. Invest. 94, 1543-1549.

Hotamisligil, G. S., Peraldi, P., Budavari, A., Ellis, R., White, M. F., and Spiegelman, B. M. (1996). IRS-1-mediated inhibition of insulin receptor tyrosine kinase activity in TNF- $\alpha$ and obesity-induced insulin resistance. Science 271, 665-668.

Hotamisligil, G. S., Shargill, N. S., and Spiegelman, B. M. (1993). Adipose expression of tumor necrosis factor$\alpha$ : direct role in obesity-linked insulin resistance. Science 259, 87-91.

Howard, G., O'Leary, D. H., Zaccaro, D., Haffner, S., Rewers, M., Hamman, R., et al. (1996). Insulin sensitivity and atherosclerosis. Circulation 93, 1809-1817.

Iglewski, M., and Grant, S. R. (2010). Urotensin II-induced signaling involved in proliferation vascular smooth muscle cells. Vasc. Health Risk. Manag. 6, 723-734.

Jaggers, J. R., Sui, X., Hooker, S. P., LaMonte, M. J., Matthews, C. E., Hand, G. A., et al. (2009). Metabolic syndrome and risk of cancer mortality in men. Eur. J. Cancer 45, 1831-1838.

Janke, J., Engeli, S., Gorzelniak, K., Feldpausch, M., Heintze, U., Böhnke, J., et al. (2006). Adipose tissue and circulating endothelial cell specific molecule-1 in human obesity. Horm. Metab. Res. 38, 28-33.

Jiang, Z., Michal, J. J., Tobey, D. J., Wang, Z., Macneil, M. D., and Magnuson, N. S. (2008). Comparative understanding of UTS2 and UTS2R genes for their involvement in type 2 diabetes mellitus. Int. J. Biol. Sci. 4, 96-102.

Johns, D. G., Ao, Z., Naselsky, D., Herold, C. L., Maniscalco, K., Sarov-Blat, L., et al. (2004). Urotensin- II-mediated cardiomyocyte hyper- trophy: effect of receptor antagonism and role of inflammatory mediators. Arch. Pharmacol. 370, 238-250.

Jovinge, S., Hamsten, A., Tornvall, P., Proudler, A., Bavenholm, P., Ericsson, C. G., et al. (1998). Evidence for a role of tumor necrosis factor in disturbances of triglyceride and glucose metabolism predisposing to coronary heart disease. Metabolism 47, 113-118.

Juhan-Vague, I., Alessi, M. C., and Vague, P. (1991). Increased plasma plasminogen activator inhibitor 1 levels. A possible link between insulin resistance and atherothrombosis. Diabetologia 34, 457-462.

Kahaleh, M. B., and Fan, P. S. (1997). Effect of cytokines on the production of endothelin by endothelial cells. Clin. Exp. Rheumatol. 15, 163-167.
Kahn, B. B., and Flier, J. S. (2000). Obesity and insulin resistance. J. Clin. Invest. 106, 473-481.

Kern, P. A., Ranganathan, S., Li, C. Wood, L., and Ranganathan, G. (2001). Adipose tissue tumor necrosis factor and interleukin-6 expression in human obesity and insulin resistance. Am. J. Physiol. Endocrinol. Metab. 280, E745-E751.

Kiss, R. S., You, Z., Genest, J. Jr., Behm, D. J., and Giaid, A. (2011). Urotensin II differentially regulates macrophage and hepatic cholesterol homeostasis. Peptides 32, 956-963.

Laimer, M., Ebenbichler, C. F., Kaser S., Sandhofer, A., Weiss, H., Nehoda H., et al. (2002). Markers of chronic inflammation and obesity: a prospective study on the reversibility of this association in middle-aged women undergoing weight loss by surgical intervention. Int. J. Obes. Relat. Metab. Disord. 26, 659-662.

Lassègue, B., and Clempus, R. E. (2003). Vascular $\mathrm{NAD}(\mathrm{P}) \mathrm{H}$ oxidases: specific features, expression, and regulation. Am. J. Physiol. Regul. Integr. Comp. Physiol. 285, 277-297.

Leinonen, E., Hurt-Camejo, E., Wiklund, O., Hulten, L. M., Hiukka, A., and Taskinen, M. R. (2003). Insulin resistance and adiposity correlate with acute-phase reaction and soluble cell adhesion molecules in type 2 diabetes. Atherosclerosis 166, 387-394.

Libby, P., Ridket, P. M., Hansson, G. K., and Leducq Transatlantic Network on Atherothrombosis. (2009). Inflammation in atherosclerosis: from pathophysiology to practice. J. Am. Coll. Cardiol. 54, 2129-2138.

Lim, M., Honisett, S., Sparkes, C. D., Komesaroff, P., Kompa, A., and Krum, H. (2004). Differential effect of urotensin II on vascular tone in normal subjects and patients with chronic heart failure. Circulation 109, 1212-1214.

Lin, Y., Tsuchihashi, T., Matsumura K., Fukuhara, M., Ohya, Y., Fujii, K., et al. (2003). Central cardiovascular action of urotensin II in spontaneously hypertensive rats. Hypertens. Res. 26, 839-845.

Liu, Q., Pong, S. S., Zeng, Z., Zhang, Q. Howard, A. D., Williams, D. L., et al. (1999). Identification of urotensin II as the endogenous ligand for the orphan G-protein-coupled receptor GPR14. Biochem. Biophys. Res. Commun. 266, 174-178.

Loirand, G., Rolli-Derkinderen, M., and Pacaud, P. (2008). Urotensin II and atherosclerosis. Peptides 29, 778-782. Maguire, J. J., Kuc, R. E., and Davenport, A. P. (2000). Orphan-receptor ligand human urotensin II: receptor localization in human tissues and comparison of vasoconstrictor response with endothelin-1. Br. J. Pharmacol. 131, 441-446.

Maguire, J. J., Kuc, R. E., Wiley, K. E., Kleinz, M. J., and Davenport, A. P. (2004). Cellular distribution of immunoreactive urotensin-II in human tissues with evidence of increased expression in atherosclerosis and a greater constrictor response of small compared to large coronary arteries. Peptides 25, 1767-1774.

Mallamaci, F., Pizzini, P., Tripepi, G., and Zoccali, C. (2005). Urotensin II in end-stage renal disease: an inverse correlate of sympathetic function and cardiac natriuretic peptides. J. Nephrol. 18, 727-732.

Matsushita, M., Shichiri, M., Imai, T. Iwashina, M., Tanaka, H., Takasu, N., et al. (2001). Co-expression of urotensin II and its receptor (GPR14) in human cardiovascular and rena tissues. J. Hypertens. 19, 2185-2190.

Mayer-Davis, E. J., D’Agostino, R. Jr., Karter, A. J., Haffner, S. M., Rewers, M. J., Saad, M., et al. (1998). Intensity and amount of physical activity in relation to insulin sensitivity: the Insulin Resistance Atherosclerosis Study. JAMA 279, 669-674.

McGarry, J. D., and Dobbins, R. L. (1999). Fatty acids, lipotoxicity and insulin secretion. Diabetologia 42 , 128-138.

McMillan, D. E. (1989). Increased levels of acute-phase serum proteins in diabetes. Metabolism 38, 1042-1046.

Misra, A., and Khurana, L. (2008). Obesity and the metabolic syndrome in developing countries. J. Clin. Endocrinol. Metab. 93(Suppl. 1), S9-S30.

Muramaki, T., Michelagnoli, S., Longhi, R., Gianfranceschi, G., Pazzucconi, F. Calabresi, L., et al. (1995). Triglycerides are major determinants of cholesterol esterification/transfer and HDL remodelling in human plasma. Atherioscler. Throm. Vasc. Biol. 15, 1819-1828.

National Cholesterol Education Program (NCEP) Expert Panel on Detection, Evaluation, and Treatment of High Blood Cholesterol in Adults (Adult Treatment Panel III). (2002). Third Report of the National Cholesterol Education Program (NCEP) Expert Panel on Detection, Evaluation, and Treatment of High Blood Cholesterol in Adults (Adult Treatment Panel III) final report. Circulation 106, 3143-3421.

Neumiller, J. J., Wood, L., and Campbell, R. K. (2010). Dipeptidyl peptidase-4 inhibitors for the treatment of type
2 diabetes mellitus. Pharmacotherapy 30, 463-484.

Nishihama, K., Yamada, Y., Matsuo, H., Segawa, T., Watanabe, S., Kato, K., etal. (2007). Association of gene polymorphisms with myocardial infarction in individuals with or without conventional coronary risk factors. Int. J. Mol. Med. 19, 129-141.

Nonogaki, K., Fuller, G. M., Fuentes, N. L., Moser, A. H., Staprans, I., and Grunfeld, C. (1995). Interleukin-6 stimulates hepatic triglyceride secretion in rats. Endocrinology 136, 21432149.

Oguri, M., Kato, K., Yokoi, K., Itoh, T., Yoshida, T., Watanabe, S., et al. (2009). Association of genetic variants with myocardial infarction in Japanese individuals with metabolic syndrome. Atherosclerosis 206, 486-493.

Ong, K. L., Wong, L. Y., and Cheug, B. M. (2008). The role of urotensin II in the metabolic syndrome. Peptides 29, 859-867.

Ong, K. L., Wong, L. Y., Man, Y. B., Leung, R. Y., Song, Y. Q., Lam, K. S., et al. (2006). Haplotypes in the urotensin II gene and urotensin II receptor gene are associated with insulin resistance and impaired glucose tolerance. Peptides 27, 16591667.

Paolisso, G., Tataranni, P. A., Foley, J. E., Bogardus, C., Howard, B. V., and Ravussin, E. (1995). A high concentration of fasting plasma nonesterified fatty acids is a risk factor for the development of NIDDM. Diabetologia 38, 1213-1217.

Papadopoulos, P., Bousette, N., AlRamli, W., You, Z., Behm, D. J., Ohlstein, E. H., et al. (2009). Targeted overexpression of the human urotensin receptor transgene in smooth muscle cells: effect of UT antagonism in ApoE knockout mice fed with Western Diet. Atherosclerosis 204, 395-404.

Papanicolaou, D. A., Petrides, J. S., Tsigos, C., Bina, S., Kalogeras, K. T., Wilder, R., etal. (1996). Exercise stimulates interleukin-6 secretion: inhibition by glucocorticoids and correlation with catecholamines. Am. J. Physiol. 271, E601-E605.

Pearson, D., Shively, J. E., Clark, B. R., Geschwind, I. I., Barkley, M., Nishioka, R. S., et al. (1980). Urotensin II antagonist peptide in the caudal neurosecretory system of fishes. Proc. Natl. Acad. Sci. U.S.A. 77, 50215024.

Popkin, B. M., and Doak, C. M. (1998). The obesity epidemic is a worldwide phenomenon. Nutr. Rev. 56, 106-114. 
Pradhan, A. D., Manson, J. E., Rifai, N., Buring, J. E., and Ridker, P. M. (2001). C-reactive protein, interleukin 6 , and risk of developing type 2 diabetes mellitus. JAMA 286, 327-334.

Randle, P. J. (1998). Regulatory interactions between lipids and carbohydrates: the glucose fatty acid cycle after 35 years. Diabetes Metab. Rev. 14, 263-283.

Randle, P. J., Garland, P. B., Hales, C. N., and Newsholme, E. A. (1963). The glucose fatty-acid cycle. Its role in insulin sensitivity and the metabolic disturbances of diabetes mellitus. Lancet 1, 785-789.

Reaven, G. M. (1988). Banting lecture 1988. Role of insulin resistance in human disease. Diabetes 37, 15951607.

Reaven, G. M. (2003). Insulin resistance/compensatory hyperinsulinemia, essential hypertension, and cardiovascular disease. J. Clin. Endocrinol. Metab. 88, 2399-2403.

Ross, B., McKendy, K., and Giaid, A. (2010). Role of urotensin II in health and disease. Am. J. Physiol. Regul. Integr. Comp. Physiol. 298, R1156-R1172.

Ruan, W., and Lai, M. (2010). Insulinlike growth factor binding protein: a possible marker for the metabolic syndrome? Acta. Diabetol. 47, 5-14.

Russell, F. D., and Molenaar, P. (2004). Investigation of signalling pathways that mediate the inotropic effect of urotensin-II in human heart. Cardiovasc. Res. 63, 673-681.

Sáez, M. E., Smani, T., Ramírez-Lorca, R., Díaz, I., Serrano-Ríos, M., Ruiz, A., et al. (2011). Association analysis of urotensin II gene (UTS2) and flanking regions with biochemical parameters related to insulin resistance. PLoS ONE 6:e19327. doi: 10.1371/journal.pone.0019327

Sako, Y., and Grill, V. E. (1990). A 48-hour lipid infusion in the rat time-dependently inhibits glucoseinduced insulin secretion and B cell oxidation through a process likely coupled to fatty acid oxidation. Endocrinology 127, 1580-1589.

Sano, M., Fukuda, K., Kodama, H., Pan, J., Saito, M., Matsuzaki, J. et al. (2000). Interleukin-6 family of cytokines mediate angiotensin II-induced cardiac hypertrophy in rodent cardiomyocytes. J. Biol. Chem. 275, 29717-22923.

Sartore, S., Chiavegato, A., Faggin, E., Franch, R., Puato, M., Ausoni, S., et al. (2001). Contribution of adventitial fibroblasts to neointima formation and vascular remodeling: from innocent bystander to active participant. Circ. Res. 89, 1111-1121.
Sauzeau, V., Le Mellionnec, E. Bertoglio, J., Scalbert, E., Pacaud, P., and Loirand, G. (2001). Human urotensin II-induced contraction and arterial smooth muscle cell proliferation are mediated by RhoA and Rho-kinase. Circ. Res. 88, 1102-1104.

Segain, J. P., Rolli-Derkinderen, M., Gervois, N., Raingeard de la Blétière, D., Loirand, G., and Pacaud, P. (2007). Urotensin II is a new chemotactic factor for UT-expressing monocytes. J. Immunol. 179, 901-909.

Sheridan, M. A., and Bern, H. A. (1986). Both somatostatin and the cauda neuropeptide, urotensin II, stimulate lipid mobilization from coho salmon liver incubated in vitro. Regul. Pept. 14, 333-344.

Sheridan, M. A., Plisetskaya, E. M. Bern, H. A., and Gorbman, A. (1987). Effects of somatostatin-25 and urotensin II on lipid and carbohydrate metabolism of coho salmon, Oncorhynchus kisutch. Gen. Comp. Endocrinol. 66, 405-414.

Silvestre, R. A., Egido, E. M., Hernández, R., Leprince, J., Chatenet, D., Tollemer, H., et al. (2004). Urotensin-II is present in pancreatic extracts and inhibits insulin release in the perfused rat pancreas. Eur. J. Endocrinol. 151, 803-809.

Silvestre, R. A., Rodríguez-Gallardo, J., Egido, E. M., and Marco, J. (2001). Inhibition of insulin release by urotensin II - a study on the perfused rat pancreas. Horm. Metab. Res. 33, 379-381.

Sondermeijer, B., Komp, A., Komesaroff, P., and Krum, H. (2005). Effects of exogenous urotensinII on vascular tone in skin microcirculation of patients with essential hypertension. Am. Hypertens. 22, 1341-1344.

Song, N., Ding, W., Chu, S., Zhao, J., Dong, X., Di, B., et al. (2012). Urotensin II stimulates vascular endothelial growth factor secretion from advential fibroblasts in synergy with angiotensin II. Circ. J. $76,1267-1273$

Sowers, J. R. (2004). Insulin resistance and hypertension. Am. J. Physiol Heart Circ. Physiol. 286, H1597H1602.

Stefan, N., Kantartzis, K., Machann, J., Schick, F., Thamer, C., Rittig, K. et al. (2008). Identification and characterization of metabolically benign obesity in humans. Arch. Intern. Med. $168,1609-1616$.

Stenmark, K. R., Davie, N., Frid, M., Gerasimovskaya, E., and Das, M. (2006). Role of the adventitia in pulmonary vascular remodelling Physiology (Bethesda) 21, 134-145.

Stirrat, A., Gallagher, M., Douglas, S. A., Ohlstein, E. H., Berry, C., Kirk, A., et al. (2001). Potent vasodilator responses to human urotensin-I in human pulmonary and abdominal resistance arteries. Am. J. Physiol. Heart Circ. Physiol. 280, H925-H928.

Stouthard, J. M., Romijn, J. A., Van der Poll, T., Endert, E., Klein, S., Bakker, P. J., et al. (1995). Endocrinologic and metabolic effects of interleukin6 in humans. Am. J. Physiol. 268, E813-E819.

Sun, H. X., Du, W. N., Zuo, J., Wu, G. D., Shi, G. B., Shen, Y., et al. (2002). The association of two single nucleotide polymorphisms in PRKCZ and UTS2 respectively with type 2 diabetes in Han people of northern China. Zhongguo Yi Xue Ke Xue Yuan Xue Bao 24 223-227.

Sutherland, J. P., McKinley, B., and Eckel, R. H. (2004). The metabolic syndrome and inflammation. Metab. Synd. Relat. Disord. 2, 82-104.

Suzuki, S., Wenyi, Z., Hirai, M., Hinokio, Y., Suzuki, C., Yamada, T. et al. (2004). Genetic variations at urotensin II and urotensin II receptor genes and risk of type 2 diabetes mellitus in Japanese. Peptides 25, 1803-1808.

Takano, M., Itoh, N., Yayama, K., Yamano, M., Ohtani, R., and Okamoto, H. (2000). Interleukin 6 as a mediator responsible for inflammation-induced increase in plasma angiotensinogen. Biochem. Pharmacol. 45, 201-206.

Tamura, K., Okazaki, M., Tamura, M., Isozumi, K., Tasaki, H., and Nakashima, Y. (2003). Urotensin II-induced activation of extracellular signal-regulated kinase in cultured vascular smooth muscle cells: involvement of cell adhesionmediated integrin signalling. Life Sci. 72, 1049-1060.

Tan, Y. J., Fan, Z. T., and Yang, H. $X$. (2006). Role of urotensin II gene in the genetic susceptibility to gestational diabetes mellitus in northern Chinese women. Zhonghua Fu Chan Ke Za Zhi 41, 732-735.

Totsune, K., Takahashi, K., Arihara, Z. Sone, M., Ito, S., and Murakami, O. (2003). Increased plasma urotensin II levels in patients with diabetes mellitus. Clin. Sci. 104, 1-5.

Trayhurn, P., and Wood, I. S. (2004). Adipokines: inflammation and the pleiotropic role of white adipose tissue. Br. J. Nutr. 92, 347-355

Tsoukas, P., Kane, E., and Giaid, A. (2011). Potential clinical implications of the urotensin II receptor antagonists. Front. Pharmacol. 2:38. doi 10.3389/fphar.2011.00038

Tzanidis, A., Hannan, R. D., and Thomas, W. G. (2003). Direct actions of urotensin II on the heart implications for cardiac fibrosis and hypertrophy. Circ. Res. 93, 246-253.

Unger, R. H. (1995). Lipotoxicity in the pathogenesis of obesity-dependant NIDDM. Genetic and clinical implications. Diabetes 44, 863-870.

Vessby, B., Unsitupa, M., Hermansen, K., Riccardi, G., Rivellese, A. A., Tapsell, L. C., et al. (2001). Substituting dietary saturated for monounsaturated fat impairs insulin sensitivity in healthy men and women: the KANWU Study. Diabetologia 44, 312-319.

Vozarova, B., Fernandez-Real, J. M., Knowler, W. C., Gallart, L., Hanson, R. L., Gruber, J. D., et al. (2003). The interleukin-6 (174) G/C promoter polymorphism is associated with type-2 diabetes mellitus in Native Americans and Caucasians. Hum. Genet. 112, 409-413.

Wang, H. X., Zeng, X. J., Liu, Y., Wang, J., Lu, L. Q., Hao, G., et al. (2009). Elevated expression of urotensin II and its receptor in skeletal muscle of diabetic mouse. Regul. Pept. 154, 85-90.

Wang, Z. J., Shi, L. B., Xiong, Z. W., Zhang, L. F., Meng, L., Bu, D. F., et al. (2006). Alteration of vascular urotensin II receptor in mice with apolipoprotein E gene knockout. Peptides 27, 858-863.

Watanabe, T., Pakala, R., and Katagiri, T. (2001a). Synergistic effect of urotensin II with mildly oxidized LDL on DNA synthesis in vascular smooth muscle cells. Circulation 104, 16-18.

Watanabe, T., Pakala, R., and Katagiri, T. (2001b). Synergistic effect of urotensin II with serotonin on vascular smooth muscle cell proliferation. J. Hypertens. 19, 2191-2196.

Watanabe, T., Suguro, T., Kanome, T., Sakamoto, Y., Kodate, S., Hagiwara, T., et al. (2005). Human urotensin II accelerates foam cell formation in human monocyte-derived macrophage. Hypertension 46, 738-744.

Watson, A. M., Lambert, G. W., Smith, K. J., and May, C. N (2003). Urotensin II acts centrally to increase epinephrine and ACTH release and cause potent inotropic and chronotropic actions. Hypertension 42, 373-379.

Welborn, T. A., Breckenridge, A., Rubinstein, A. H., Dollery, C. T., and Fraser, 
T. R. (1966). Serum-insulin in essential hypertension and in peripheral vascular disease. Lancet 1, 13361337.

Wenyi, Z., Suzuki, S., Hirai, M., Hinokio, Y., Tanizawa, Y., Matsutani, A., et al. (2003). Role of urotensin II gene in genetic susceptibility to Type 2 diabetes mellitus in Japanese subjects. Diabetologia 46, 972-976.

World Health Organization. (2008). Controlling the Global Obesity Epidemic. Available at: http://www.who. int/nutrition/topics/obesity/en/in dex.html [accessed August 2012].

Yi, L., Gu, Y. H., Wang, X. L., An, L. Z., Xie, X. D., Shao, W., et al. (2006). Association of ACE, ACE2 and UTS2 polymorphisms with essential hypertension in Han and Dongxiang populations from north-western China. J. Int. Med. Res. 34, 272-283.

Yoshimoto, T., Matsushita, M., and Hirata, Y. (2004). Role of urotensin II in peripheral tissue as an autocrine/paracrine growth factor. Peptides 25, 1775-1781.

You, Z., Genest, J. Jr., Barrette, P. O., Hafiane, A., Behm, D. J., D'OrleansJuste, P., et al. (2012). Arterioscler. Thromb. Vasc. Biol. 32, 1809-1816.
Yudkin, J. S., Stehouwer, C. D., Emeis, J. J., and Coppack, S. W. (1999). C-reactive protein in healthy subjects: associations with obesity, insulin resistance, and endothelial dysfunction: a potential role for cytokines originating from adipose tissue? Artherioscler. Thromb. Vasc Biol. 19, 972-978.

Zavaroni, I., Ardigò, D., Zuccarelli, A., Pacetti, E., Piatti, P. M. Monti, L., et al. (2006). Insulin resistance/compensatory hyperinsulinemia predict carotid intimal media thickness in patients with essential hypertension. Nutr. Metab. Cardiovasc. Dis. 16, 22-27.

Zhang, Y., Li, J., Cao, J., Chen, J., Yan, J., Zhang, Z., etal. (2002). Effect of chronic hypoxia on contents of urotensin II and its functional receptors in rat myocardium. Heart Vessels $16,64-68$.

Zhang, Y. G., Li, J., Li, Y. G., and Wei, R. H. (2008). Urotensin II induces phenotypic differentiation, migration and collagen synthesis of adventitial fibroblasts from rat aorta. J. Hypertens. 26, 1119-1126.

Zhou, P., Wu, S. Y., Yu, C. F., Wang, H., Tang, C. S., Lin, L., et al. (2003). Effects of urotensin II on isolated rat hearts under normal perfusion and ischemia reperfusion. Sheng $\mathrm{Li} \mathrm{Xue}$ Bao 55, 442-448.

Zoccali, C., Mallamaci, F., Tripepi, G., Cutrupi, S., Pizzini, P., and Malatino, L. (2006). Urotensin II is an inverse predictor of incident cardiovascular events in end-stage renal disease. Kidney Int. 69, 1253-1258.

Zoccali, C., and Mallamaci, F. (2008). Urotensin II: a cardiovascular and renal update. Curr. Opin. Nephrol. Hypertens. 17, 199-204.

Zhu, F., Ji, L., and Luo, B. (2002). The role of urotensin II gene in the genetic susceptibility to type 2 diabetes in Chinese population. Zhonghua Yi Xue Za Zhi 82, 1473-1475.

Zhu, Y., Zhu, Y., and Moore, P. (2006). The role of urotensin II in cardiovascular and renal physiology and diseases. Br. J. Pharmacol. 148 884-901.

Zou, M. H., Cohen, R. A., and Ullrich, V. (2004). Peroxynitrite and vascular endothelial dysfunction in diabetes mellitus. Endothelium 11, 89-97.

Zuliani, G., Volpato, S., Ble, A., Bandinelli, S., Corsi, A. M., Lauretani, F., etal. (2007). High interleukin-6 plasma levels are associated with low HDL-C levels in community-dwelling older adults: the In Chianti study. Atherosclerosis 192, 384-390.

Conflict of Interest Statement: The authors declare that the research was conducted in the absence of any commercial or financial relationships that could be construed as a potential conflict of interest.

Received: 29 August 2012; accepted: 29 November 2012; published online: 28 December 2012.

Citation: Barrette P-O and Schwertani AG (2012) A closer look at the role of urotensin II in the metabolic syndrome. Front. Endocrin. 3:165. doi: 10.3389/ fendo.2012.00165

This article was submitted to Frontiers in Neuroendocrine Science, a specialty of Frontiers in Endocrinology.

Copyright (C) 2012 Barrette and Schwertani. This is an open-access article distributed under the terms of the Creative Commons Attribution License, which permits use, distribution and reproduction in other forums, provided the original authors and source are credited and subject to any copyright notices concerning any third-party graphics etc. 